\author{
Iwo Jarosz ${ }^{*}$ \\ ORCID: 0000-0003-3671-1982 \\ Uniwersytet Jagielloński
}

DOI: $10.19195 / 1733-5779.25 .4$

\title{
Obowiązek wniesienia wkładu w spółkach osobowych. Uwagi krytyczne
}

\section{JEL Classification: K200}

Słowa kluczowe: spółki osobowe, wkład, obowiązek, kapitał

Keywords: partnerships, contributions, obligations, capital

\begin{abstract}
Abstrakt: Istotną cechą regulacji spółek osobowych w prawie polskim jest ukształtowanie wkładów wspólników jako obligatoryjnych elementów umowy spółki. Wkłady muszą zostać przez wspólników w umowie spółki określone i wniesione do jej majątku. Specyfika spółek osobowych, które w konstrukcji normatywnej przyjętej przez prawo polskie zostały pozbawione podmiotowości prawnej w okresie przed rejestracją, utrudnia wykonanie tego obowiązku w przypadku niektórych przedmiotów wkładów, takich jak prawo własności nieruchomości, i zmusza do konstruowania złożonych mechanizmów teoretycznych mających umożliwić wniesienie takich wkładów. Z niedopuszczalnością funkcjonowania spółek osobowych jako bezwkładowych koresponduje także nakaz, aby wkłady wniósł każdy ze wspólników.

Celem niniejszego artykułu jest zbadanie i zweryfikowanie, czy takie ukształtowanie regulacji spółek osobowych w prawie polskim, które zakłada konieczność określenia i wniesienia przez każdego wspólnika wkładu, jest praktyczne i korzystne z punktu widzenia celów, jakie ma spełniać, oraz wartości, jakie ma chronić. Artykuł ma także wykazać, że uzasadnienia obecnej regulacji nie dostarczają względnej ochrony wierzycieli, która w spółkach osobowych realizowana jest nade wszystko poprzez konstrukcję osobistej odpowiedzialności wspólników. Tekst ma również pokazać, że argumentem za obecną regulacją, przy braku jakichkolwiek progów określających minimalną wysokość wkładu, nie są także kwestie ochrony obrotu prawnego przed powstawaniem podmiotów niespełniających tzw. testu powagi. Przy pomocy metody formalno-dogmatycznej badaniu zostaną poddane właściwe regulacje prawa polskiego - przepisy kodeksu spółek handlowych. Zastosowanie metod komparatystycznych pozwoli z kolei na skonstruowanie kolejnych argumentów, opartych na kierunku rozwoju prawa europejskiego oraz ustawodawstw poszczególnych państw kontynentalnej kultury prawnej, świadczących o celowości i racjonalności przyjęcia w odniesieniu do spółek osobowych konstrukcji bezwkładowej. W konkluzji wykazano, że istnieją rozsądne powody przyjęcia dopuszczalności powstawania spółek bezwkładowych jako docelowego modelu ich regulacji w polskim prawie spółek handlowych.
\end{abstract}

* Opiekun naukowy (Scientific Tutor) — Fryderyk Zoll 


\title{
The obligation to make contributions to partnerships. Critical remarks
}

\begin{abstract}
An important feature of the regulation of partnerships in Polish law is that contributions are shaped as mandatory elements. Contributions need to be determined by the partners in the partnership agreement and made, i.e. transferred to the partnership's assets. The peculiar aspect of partnerships which is their normative model providing for their lack of legal capacity prior to registration impedes obedience to this requirement in the case of certain contributions, such as real property, compelling the lawyers to construct elaborate theoretical mechanisms aiming to allow the making of such contributions. Parallel to the inadmissibility of contribution-less partnerships is the requirement that all partners make contributions. This text aims to examine and verify whether such shape of the partnerships' model in Polish law, placing on each and every partner a requirement to determine in the partnership agreement and make contributions, is practically beneficial, given the aims it is deemed to pursue as well as the values it is supposed to protect. The author argues that the protection of creditors does not constitute proper justification for the contemporary regulation, as in the case of partnerships such protection is effected, above all, through the partners' personal liability. The text shall also show that, given the lack of any threshold regulating the minimal contribution, the issues of protecting the legal relations from the establishment of entities failing to pass the so-called gravity test. The author will examine the provisions of Polish law - namely, the Code of Commercial Companies - employing the formal-dogmatic method. Comparative methods will also be utilized, allowing to construe further arguments based on the development of the European law and the laws of certain member states, showing the advisability and rationality of accepting the contributions-less model with respect to partnerships. Therefore, there exist convincing reasons to allow the establishment of contribution-less partnerships.
\end{abstract}

\section{Wstęp}

Wkład w spółkach osobowych stanowi obligatoryjną formę przyczynienia się wspólnika do powstania spółki. Wynika to w jasny sposób z przepisów. Przyjmuje się, że wkład służy wyposażeniu spółki w majątek, a zobowiązanie się wspólników do jego wniesienia warunkuje powstanie spółki jako odrębnego podmiotu prawa. Wniesienie wkładu ma też pozwalać na wyposażenie spółki w aktywa umożliwiające podjęcie przez nią działalności gospodarczej ${ }^{1}$.

Znaczenie wnoszonych przez wspólników wkładów dla praktycznych aspektów funkcjonowania spółek osobowych jest jednak niewielkie. Składa się na nie wąski zbiór powiązanych luźno z wkładami uprawnień i obowiązków wspólników. Konieczność wniesienia wkładów od samego początku bytu spółki, od chwili zawarcia umowy spółki osobowej, jest jednak utrudnieniem i wpływa na pojawienie się wielu praktycznych problemów. Spółki osobowe powstają dopiero $\mathrm{z}$ chwilą rejestracji ${ }^{2}$. Okres pomiędzy zawarciem umowy spółki a jej rejestracją jest okresem w zasadzie nieuregulowanym, którego prawna ocena jest $\mathrm{w}$ doktry-

${ }^{1}$ Niniejsza uwaga jest aktualna zwłaszcza w odniesieniu do spółek osobowych, które mogą być tworzone jedynie w celu prowadzenia przedsiębiorstwa.

2 Od chwili wejścia w życie ustawy z dnia 12 grudnia 2003 roku o zmianie ustawy — Kodeks spółek handlowych oraz niektórych innych ustaw (Dz.U. Nr 229, poz. 2276) z dniem 1 stycznia 2004 roku dotyczy to wszystkich typów spółek osobowych, w tym spółki jawnej. 
nie notoryjnie sporna. Praktyczną konsekwencją takiego stanu rzeczy są trudności związane z konstrukcją prawną wniesienia wkładów do takich spółek ${ }^{3}$, co dotyczy zwłaszcza problematyki wkładów niepieniężnych, głównie nieruchomości ${ }^{4}$.

Spółki osobowe stanowią atrakcyjną formułę dla potrzeb prowadzenia działalności gospodarczej. Przyczynami takiego stanu rzeczy mogą być między innymi brak podwójnego opodatkowania oraz liberalne regulacje dotyczące wewnętrznych stosunków w spółce, umożliwiające wspólnikom głębokie i elastyczne modyfikacje. Nie oznacza to jednak, że regulacji spółek osobowych nie można poprawić, a przede wszystkim uprościć. Dotyczy to w szczególności kwestii wkładów, stanowiących w polskim prawie obligatoryjny element umów spółek osobowych. Funkcje, jakie ma pełnić taka regulacja, po wnikliwej analizie mogą okazać się niewłaściwie zidentyfikowane bądź nawet zbędne. Obserwując żywą i trwającą w europejskiej i polskiej doktrynie prawa spółek krytykę regulacji kapitału zakładowego w spółkach z ograniczoną odpowiedzialnością, warto postawić sobie pytanie o aktualność i celowość wniesienia wkładu do spółek osobowych jako obowiązku wspólników.

\section{Obowiązek wniesienia wkładu w spółkach osobowych}

Obowiązek wniesienia wkładu został wprost uregulowany w Kodeksie spółek handlowych. Przede wszystkim znalazł się on w art. 3 k.s.h. ${ }^{5}$, określającym elementy wspólne wszystkich umów spółek handlowych ${ }^{6}$. Obowiązek wniesienia wkładu jest koniecznym elementem każdej umowy spółki handlowej ${ }^{7}$. Przedstawiciele doktryny częstokroć z tego powodu zaliczają go zatem do essentialia negotii umowy spółki handlowej jako takiej ${ }^{8}$.

3 Zob. W. Górecki, Konstrukcja wnoszenia przez wspólników wkładów do handlowych spótek osobowych, „Transformacje Prawa Prywatnego” 2012, nr 2; S. Włodyka, Problem osobowych spótek $w$ organizacji, ,Rejent” 2003, nr 6, s. 262.

${ }^{4}$ G. Bieniek, Nieruchomość jako wktad niepieniężny, [w:] Prawo prywatne czasu przemian. Ksiegga pamiątkowa dedykowana Profesorowi Stanisławowi Soltysińskiemu, red. A. Nowicka, Poznań 2005; I. Jarosz, Konstrukcja prawna wniesienia do spótki osobowej wkładu niepieniężnego ze szczególnym uwzględnieniem nieruchomości, „Internetowy Przegląd Prawniczy TBSP UJ” 2017, nr 9, s. 90-109; M. Kutyła, Prawa na nieruchomości jako aport, „Monitor Prawniczy” 1999, nr 4.

5 Ustawa z dnia 15 września 2000 roku - Kodeks spółek handlowych (tekst jedn. Dz.U. z 2017 r. poz. 1577 ze zm.).

6 Tak W. Pyzioł, [w:] Kodeks spótek handlowych. Komentarz, red. W. Pyzioł et al., Warszawa 2008, s. 13.

7 W. Pyzioł, op. cit. Por. także M. Rodzynkiewicz, Kodeks spólek handlowych. Komentarz, Warszawa 2014, s. 1; R. Siwik, [w:] Kodeks spólek handlowych. Komentarz, red. Z. Jara, Warszawa 2014, s. 16.

8 Tak np. A. Szajkowski, Umowa spółki handlowej, „Studia Prawnicze” 2001, nr 3-4, s. 322; A. Szajkowski, M. Tarska, [w:] Kodeks spółek handlowych. Komentarz, t. 1, red. S. Sołtysiński et al., Warszawa 2012, s. 59; M. Minas, Aport w spółce kapitałowej, Gdańsk 2005, s. 7; A. Kidyba, 
Stanowisko to poddawane jest również krytyce. Wskazuje się, że nie ma jednolitej, odnoszącej się do wszystkich rodzajów spółek definicji umowy spółki prawa handlowego ${ }^{9}$. Zauważono, że spółka handlowa nie jest nigdy spółką w ogóle, lecz zawsze spółką handlową określonego typu (np. jawną, partnerską) ${ }^{10}$. Niektórzy uznają zatem, że przepis art. 3 k.s.h. zawiera jedynie katalog wspólnych i obligatoryjnych elementów każdej umowy spółki handlowej. Ponadto wskazuje się, że elementy umowy spółki handlowej wymienione w art. 3 k.s.h. stanowią „,cechy wspólne dla stosunków spółek handlowych oraz innych stosunków prawnych jednostek organizacyjnych, takich jak m.in. europejskie zgrupowania interesów gospodarczych, spółdzielnie itd."11, zatem nie sposób ich uznawać za essentialia negotii umowy spółki handlowej. Dopiero wraz z cechami wskazanymi w przepisach k.s.h., definiującymi konkretne spółki osobowe (art. 22, art. 86, art. 102, art. 125 k.s.h.), elementy z art. 3 k.s.h. stanowią essentialia negotii dla poszczególnych typów spółek - dla każdego z nich z osobna ${ }^{12}$. Niezależnie od podejścia do tej kwestii istota rzeczy pozostaje niezmienna: w przypadku wszystkich znanych polskiemu prawu typów spółek osobowych art. 3 k.s.h znajduje wprost zastosowanie, statuując obowiązek wniesienia wkładu. Taki wniosek potwierdza również lektura uzasadnienia projektu Kodeksu spółek handlowych, w którym wskazano, że obowiązek wniesienia wkładu przez każdego ze wspólników nie jest „tylko jedną z możliwych postaci współdziałania stron”, a ponadto, że „warunek wniesienia wkładów jest więc również essentiale negotii wszystkich osobowych spółek handlowych"13.

Zgodnie $\mathrm{z}$ art. 3 k.s.h. niedopuszczalne jest powstanie spółki bezwkładowej ${ }^{14}$. Doktryna okresu Kodeksu handlowego przyjmowała niekiedy dopuszczalność powołania do życia takiego tworu ${ }^{15}$. Brzmienie art. 3 k.s.h. nie pozostawia jednak wątpliwości — obecnie powstanie spółki osobowej bez wcześniejszego określenia

Handlowe spótki osobowe, Warszawa 2013, s. 106; J.A. Strzępka, E. Zielińska, [w:] Kodeks spótek handlowych. Komentarz, red. J.A. Strzępka, Warszawa 2013, s. 19; S. Włodyka, [w:] System Prawa Handlowego, t. 2. Prawo spółek handlowych, red. S. Włodyka, Warszawa 2012, s. 151.

9 W. Pyzioł, op. cit., s. 14; R. Siwik, op. cit., s. 15-16.

10 W. Pyzioł, op. cit., s. 14. Zdaniem tego autora możliwe jest konstruowanie tylko definicji poszczególnych typów spółek.

11 M. Spyra, [w:] J. Bieniak et al., Kodeks spótek handlowych. Komentarz. Legalis/el. 2017, komentarz do art. 3 k.s.h., nb. 1.

12 Ibidem. Analogiczne wnioski wynikają z cytowanego wyżej stanowiska W. Pyzioła.

13 Uzasadnienie projektu ustawy - Kodeks spółek handlowych, druk nr 1687, Sejm RP III kadencji, projekt z dnia 4 lutego 2000 roku, s. 26 uzasadnienia.

14 W. Pyzioł, op. cit., s. 15; M. Rodzynkiewicz, op. cit. s. 2; J.A. Strzępka, E. Zielińska, op. cit., s. 20.

15 Tak np. A.W. Wiśniewski, Prawo o spółkach. Podręcznik praktyczny, t. 2, Warszawa 1991, s. 27. Zob. także S. Sołtysiński, [w:] S. Sołtysiński et al., Kodeks handlowy, Warszawa 1994, s. 537. Z kolei przeciwny dopuszczalności konstrukcji spółki bezwkładowej był m.in. M. Allerhand (idem, Kodeks handlowy, t. I, Lwów 1935, reprint Bielsko-Biała 1991, s. 160). 
wkładów, które mają być wniesione przez wszystkich wspólników, nie jest możliwe ${ }^{16}$. Podobnie wykluczone jest zwolnienie któregokolwiek wspólnika z tego obowiązku ${ }^{17}$. Ustawa nie zna również instytucji bezwkładowego uczestnictwa w spółce przez wspólnika zwolnionego z obowiązku wniesienia wkładu. Zobowiązanie do wniesienia wkładu o wartości czysto symbolicznej uważa się za obejście prawa ${ }^{18}$, co będzie się odnosić do wszystkich rodzajów spółek osobowych ${ }^{19}$.

Krytykę przedstawionej wykładni art. 3 k.s.h. należy postrzegać wyłącznie w kategorii postulatów de lege ferenda. Należy przy tym zauważyć, że współczesne ustawodawstwa europejskie, w szczególności w odniesieniu do regulacji spółek z ograniczoną odpowiedzialnością, zdołały wykreować inne modele funkcjonowania spółek aniżeli art. 3 k.s.h., zakładający obowiązek wniesienia wkładu.

Artykuł 25 pkt 2 k.s.h. pośród koniecznych elementów umowy spółki jawnej przewiduje konieczność określenia wkładów wnoszonych przez każdego wspólnika i ich wartości. Sposób wyrażenia tego przepisu (,przez każdego wspólnika...”) potwierdza, że obowiązek wniesienia wkładu dotyczy każdego ze wspólników, a umowa spółki nie może zwalniać niektórych z nich z tego zobowiązania. Obowiązek wniesienia wkładu został podobnie uregulowany na gruncie przepisów o spółce partnerskiej. Artykuł 91 pkt 7 k.s.h. stanowi, podobnie jak art. 25 pkt 2, o konieczności oznaczenia w umowie spółki partnerskiej wkładów wnoszonych przez każdego partnera, a także ich wartości.

Również odnośnie do spółki komandytowej art. 105 pkt 4 k.s.h. przewiduje obowiązek oznaczenia wkładu każdego wspólnika oraz jego wartości w umowie tego rodzaju spółki. Pośród przepisów odnoszących się do wkładów w spółce komandytowej wątpliwości interpretacyjne może nasuwać art. $108 \S 2$ k.s.h. stanowiący o niedopuszczalności zwolnienia komandytariusza od obowiązku wniesienia wkładu. Jego treść prowadzi niektórych przedstawicieli doktryny do wysunięcia, na podstawie argumentum a contrario, wniosku o dopuszczalności takiego zwolnienia w odniesieniu do komplementariuszy ${ }^{20}$. W kontekście jednoznacznego brzmienia art. 3 k.s.h. i art. 105 pkt 4 k.s.h. należy jednak podkreślić niedopuszczalność zwolnienia z obowiązku wniesienia wkładu zarówno komandytariuszy,

16 S. Sołtysiński, [w:] Kodeks spółek handlowych t. 1, red. S. Sołtysiński et al., s. 424; W. Pyzioł, op. cit., s. 14.

17 S. Sołtysiński, [w:] System Prawa Prywatnego, t. 16. Prawo spótek osobowych, red. A. Szajkowski, s. 826; K. Kopaczyńska-Pieczniak, Pozycja prawna wspólnika spótki jawnej, Warszawa 2012, s. 303.

18 K. Kopaczyńska-Pieczniak, op. cit., s. 304.

19 Tak samo zresztą wypadałoby chyba ocenić zobowiązanie do wniesienia wkładu o wartości namacalnej, lecz z terminem świadczenia odroczonym na czas nierozsądnie długi (np. obowiązek świadczenia wkładu w wysokości $100000 \mathrm{zł} \mathrm{za} 45$ lat).

20 Tak np. A. Szumański, [w:] System Prawa Prywatnego, t. 16, s. 930; W. Górecki, [w:] System Prawa Handlowego..., s. 676; A. Kidyba, Kodeks spółek handlowych. Komentarz, t. 1. wyd. 10, Warszawa 2013, s. 464. 
jak i komplementariuszy ${ }^{21}$. Wynika ona z brzmienia art. 3 k.s.h., a także art. 105 pkt 4 k.s.h., których zasad nie może obalić art. $108 \S 2$ k.s.h. ${ }^{22}$ Przepis art. $108 \S 2$ k.s.h. potwierdza tę zasadę w odniesieniu do komandytariuszy, względnie: stanowi prozaicznie superfluum ustawowe ${ }^{23}$ bądź też przepis służący rozstrzygnięciu z góry wątpliwości co do możliwości zwolnienia komandytariuszy z obowiązku wniesienia wkładu ${ }^{24}$. M. Spyra zauważa nadto, że status komplementariusza spółki komandytowej odpowiada w pełni statusowi wspólnika spółki jawnej, zatem ,uregulowanie w kodeksie jakichkolwiek przepisów regulujących status komandytariusza samo w sobie nie jest wystarczającą przesłanką dla rozumowania a contrario w odniesieniu do pozycji prawnej komplementariusza" 25 .

Problematyka wniesienia wkładu do spółki komandytowo-akcyjnej ma dwa aspekty, a to ze względu na hybrydalny, osobowo-kapitałowy charakter tej spółki. Odrębnie należy rozważać kwestię wniesienia wkładu przez komplementariuszy, do których należy stosować przepisy dotyczące spółek osobowych (art. $126 \S 1$ pkt 1 k.s.h.), odrębnie zaś przez akcjonariuszy. W tym wypadku bowiem zastosowanie znajdą przepisy odnoszące się do spółki akcyjnej (art. $126 \S 1$ pkt 2 k.s.h.). W spółce komandytowo-akcyjnej zatem obowiązek wniesienia wkładu spoczywa zarówno na komplementariuszach, jak i akcjonariuszach. W przypadku komplementariusza określenie przedmiotu wkładu i jego wartości następuje w statucie (art. 130 pkt 4 k.s.h.), zaś wnoszenie wkładu - według reguł przepisanych dla spółki jawnej (art. $126 \S 1$ pkt 1 k.s.h.), przy czym trzeba zauważyć, że chodzi tutaj o wkłady wnoszone na kapitały inne niż zakładowy. W przypadku akcjonariuszy określenie przedmiotu i wartości wkładu wynika z oświadczenia o objęciu akcji (art. 313 w zw. z art. $126 \S 1$ pkt 2 k.s.h.), podobnie jak w wypadku komplementariusza wnoszącego wkłady na kapitał zakładowy, który wtedy stanie się akcjonariuszem, zaś do takiego wniesienia stosuje się reguły odpowiednie dla spółki akcyjnej (art. $126 \S 1$ pkt 2 k.s.h.). Zatem także w spółce komandytowo-akcyjnej istnieje bezwzględny obowiązek wniesienia przez wspólników wkładów do spółki.

Niezamieszczenie w umowie spółki handlowej postanowień określających wkłady wszystkich wspólników oraz ich wartości skutkuje, zgodnie z powszechną

21 Tak J. Szwaja, I.B. Mika, [w:] Kodeks spółek handlowych t. 1, red. S. Sołtysiński et al., s. 852; H. Urbańczyk, [w:] Kodeks spótek handlowych. Komentarz, red. J.A. Strzępka, s. 220; P. Pinior, [w:] Kodeks spótek handlowych. Komentarz, red. J.A. Strzępka, s. 193-195; J.P. Naworski, [w:] Kodeks spółek handlowych. Komentarz, t. 1, red. T. Siemiątkowski, R. Potrzeszcz, Warszawa 2010, s. 497; M. Rodzynkiewicz, op. cit., s. 170.

22 Tak P. Pinior, op. cit., s. 193-195.

23 J.P. Naworski, op. cit., s. 497.

24 P. Pinior, op. cit., s. 188-189.

25 M. Spyra, op. cit., s. 390. 
opinią doktryny, nieważnością umowy w całości w związku art. 58 k.c. ${ }^{26}$ Nieokreślenie w umowie spółki wkładów wspólnika winno wiązać się z odmową wpisania spółki do rejestru przedsiębiorców przez sąd rejestrowy ${ }^{27}$. Warto w tym miejscu wskazać odmienność regulacji spółki handlowej od spółki cywilnej. W przypadku tej drugiej niezamieszczenie w umowie postanowień odnoszących się do obowiązku wniesienia wkładu skutkuje niezaistnieniem takiego obowiązku, zaś umowa spółki co do zasady pozostanie ważna (art. 860 k.c. ${ }^{28}$ określa wniesienie wkładu jako jeden z przykładów wspólnego działania wspólników w sposób oznaczony, wszakże niekonieczny i niejedyny ${ }^{29}$ ).

\section{Funkcje wkładu w spółkach osobowych. Uwagi krytyczne}

Roli wkładu w spółkach osobowych doszukiwać się można w pierwszej kolejności bezpośrednio w k.s.h., w kontekście instytucji udziału kapitałowego. Dostrzega się także inne funkcje wkładów, które mają uzasadniać istnienie obowiązku ich wnoszenia w spółkach osobowych. Nie wydają się one jednak przekonujące. Żadna z możliwych do pomyślenia funkcji wkładów w spółkach osobowych nie stanowi argumentu za dalszym utrzymywaniem wymogu wniesienia wkładu jako definitywnego i konstytutywnego dla spółek osobowych.

Wkłady wspólników w modelowym, domyślnym ustroju spółki jawnej (znajdującym poprzez stosowne odesłania zastosowanie do innych spółek osobowych) pełnią rolę zapośredniczoną w insty tucji udziału kapitałowego. Udział kapitałowy jest pewną wartością rachunkową odpowiadającą wartości wkładu rzeczywiście wniesionego (co należy odróżnić od wkładu umówionego). Udział kapitałowy jest wartością zmienną ${ }^{30}$ - początkowo zerowy, w miarę wnoszenia wkładu (np. w częściach) rośnie, ostatecznie mogąc osiągnąć kwotę równą wartości wkładu umówionego ${ }^{31}$. Udział kapitałowy w ramach domyślnego ustroju spółki osobowej (który może zostać praktycznie w całości ukształtowany odmiennie — art. 37 $\S 2$ k.s.h.) służy jako podstawa do obliczenia odsetek należnych wspólnikowi (art.

26 Tak np. W. Pyzioł, op. cit., s. 76; S. Włodyka, [w:] System Prawa Handlowego, t. 2, s. 161; S. Sołtysiński, [w:] Kodeks spótek handlowych t. 1, red. S. Sołtysiński et al., s. 424.

27 Tak G. Nita-Jagielski, [w:] Bieniak et al., op. cit., s. 159.

28 Ustawa z dnia 23 kwietnia 1964 roku — Kodeks cywilny (tekst jedn. Dz.U. z 2017 r. poz. 459 ze zm.).

29 Tak np. T. Sójka, R. Szyszko, [w:] Kodeks cywilny, t. 2. Komentarz do art. 450-1088, red. M. Gutowski, Legalis/el. 2016, komentarz do art. 860 k.c. nb. 5, powołujący obszernie inne wypowiedzi doktryny. Nie przekonują w tej mierze wywody A. Nowackiego w: Kodeks cywilny. Komentarz, red. K. Osajda, Legalis/el. 2018, komentarz do art. 860 k.c., tezy 18-21.

30 Tak de facto W. Pyzioł, op. cit., s. 117, choć w ujęciu tego autora jest ona stała w tym sensie, że bez zmiany umowy spółki maksymalna wysokość udziału kapitałowego nie przekroczy wartości wkładu umówionego. Jednak autor ten przyjmuje, że wysokość może fluktuować w zakresie między zerem a wartością wkładu umówionego.

31 W. Pyzioł, op. cit., s. 117. 
53 k.s.h.), stanowi równowartość kwoty mającej zostać wypłaconą wspólnikowi w razie wystąpienia ze spółki, usunięcia go z niej lub śmierci (art. 65 k.s.h.) i jest jedną z podstaw do rozdzielenia majątku spółki po likwidacji (art. 82 § 2). Udział kapitałowy stanowi również próg, poniżej którego — bez zgody pozostałych wspólników — nie może spaść zaangażowanie kapitałowe wspólnika w spółkę (art. 54 k.s.h.).

Niezależnie od oceny instytucji udziału kapitałowego, która również jest poddawana krytyce ${ }^{32}$, należy dostrzec, że nie może ona stanowić argumentu za utrzymywaniem wymogu wniesienia wkładu w spółkach osobowych. Udział kapitałowy bowiem od czasu nowelizacji k.s.h. ${ }^{33}$ został powiązany z wkładem rzeczywiście wniesionym, nie zaś umówionym bądź określonym w umowie spółki ${ }^{34}$. Jest to rozwiązanie zasługujące na aprobatę. Podstawą wszelkich rozliczeń między spółką a wspólnikami powinna być wartość rzeczywistych świadczeń wspólnika na rzecz spółki - co zapewnia oparcie tych rozliczeń na instytucji kapitału zakładowego - a nie wartość obejmująca także niewykonane zobowiązania do wniesienia wkładu do wysokości wkładu umówionego ${ }^{35}$. Nie ma przeszkód, by zachować obecną regulację w tym kształcie, rezygnując z przymusowości wniesienia wkładu w ogóle. Można sobie wyobrazić funkcjonowanie osobowych spółek bezwkładowych, w których obowiązku wniesienia wkładu nie ma, jednak pewne osiowe kwestie, tak jak obecnie udział kapitałowy, determinowane są wysokością wkładu rzeczywiście wniesionego. Ta zaś możliwa jest do księgowego wyodrębnienia od wkładu umówionego, także przy braku ustawowego obowiązku wniesienia wkładu. Po wtóre, liberalna, oparta na przepisach dyspozytywnych regulacja spółek osobowych pozwala wspólnikom na odmienne przesądzenie zagadnień determinowanych ustawowo udziałem kapitałowym. Również w razie ustawowej „bezwkładowości” wspólnicy mogliby we własnym zakresie kształtować stosunki wewnętrzne w spółkach osobowych według swojej woli - co zresztą obecnie czynią — jak się wydaje, nader często rezygnując z ustawowego wiązania udziału kapitałowego z istotnymi prawami i obowiązkami w spółkach.

Jako inne funkcje wkładu w spółce osobowej wskazuje się m.in. ${ }^{36}$ umożliwienie jej osiągnięcia celu gospodarczego oraz potrzebę ochrony bezpieczeństwa obrotu. Żadna z nich nie wydaje się wiązać z przekonującym argumentem za istnieniem obowiązku wniesienia wkładu.

32 Zob. W. Pyzioł, [w:] W. Pyzioł, A. Szumański, I. Weiss, Prawo spółek, Warszawa 2014, s. 59.

33 Dokonanej ustawą powołaną w przyp. 3.

34 Jest to zresztą realizacja słusznego postulatu wysuniętego uprzednio przez A. Kidybę w: O potrzebie zmian w kodeksie spótek handlowych (w przepisach części ogólnej dotyczących spótek osobowych i spótki z o.o.), „Przegląd Prawa Handlowego” 2002, nr 10, s. 36.

35 Ibidem.

36 Za: M. Romanowski, [w:] System Prawa Prywatnego, t. 16. Prawo spótek osobowych, red. A. Szajkowski, s. 127. 
Osiągnięcie celu gospodarczego, jak każde zjawisko obrotu gospodarczego, uzależnione jest prakseologicznie od spełnienia pewnych wymogów, do których z pewnością należy wyposażenie podmiotu będącego prawnym wehikułem przedsięwzięcia gospodarczego w środki umożliwiające działalność. Wydaje się jednak, że jest to praktyczny problem wspólników, nie zaś obszar zainteresowania ustawodawcy. Ustawa nie przewiduje żadnych wymogów kwotowych co do wysokości wkładu ani możliwości kontroli wartości i przedmiotu wkładu w kontekście zamierzonego celu. W czym zatem miałaby wyrażać się owa funkcja wkładu? Regulacja spółki cywilnej ${ }^{37}$, jak wskazano, nie przewiduje obowiązku wniesienia wkładu. Dowodzi możliwości ukształtowania regulacji stosunku prawnego służącego realizowaniu celu, najczęściej gospodarczego, i to najczęściej w drodze prowadzenia przedsiębiorstwa, bez kształtowania obowiązku wniesienia wkładu. Różnice między czysto kontraktowym charakterem spółki cywilnej a „ułomną osobowością prawną" spółek osobowych nie są oczywiście pomijanym czynnikiem. Jednak w omawianym kontekście nie sposób dostrzec takich różnic, które kazałyby zmienić stanowisko. Specyfika spółek osobowych wynikająca z podmiotowości prawnej wyraża się w odrębności majątkowej i subsydiarności odpowiedzialności wspólników ${ }^{38}$. Te elementy zaś nie znajdują przełożenia na wnioski o konieczności wykluczenia spółek bezwkładowych na gruncie regulacji spółek osobowych.

$\mathrm{Z}$ kolei druga $\mathrm{z}$ omawianych funkcji, czyli ochrona bezpieczeństwa obrotu, wyraża się, jak się wydaje, w dwóch płaszczyznach. Jedną jest — by zapożyczyć określenie z doktryny prawa spółek kapitałowych — test powagi, drugą zaś kwestie ochrony wierzycieli.

O teście powagi mówi się w odniesieniu do spółek kapitałowych w kontekście minimalnego kapitału zakładowego jako instrumentu zniechęcającego do sięgania po formę prawną spółki kapitałowej osoby przypadkowe, niegodne zaufania, pochopnie zakładające spółkę. Abstrahując od krytyki testu powagi jako rozwiązania znanego regulacji spółki z o.o. (która w dużej mierze wynika z symboliczności kwoty minimalnego kapitału zakładowego spółki z o.o. w prawie polskim, sam test powagi zaś coraz częściej zyskuje na powrót uznanie ${ }^{39}$ ), należy zauważyć jego absolutną nieadekwatność w odniesieniu do spółek osobowych. Po pierwsze, brak minimalnej przepisanej wartości wkładu w istocie wyklucza możliwość przeprowadzenia takiego testu. Oparcie się na kryterium symboliczności wkładu (w tym zakresie konstatacja sądu o symboliczności wkładu, ergo nieważności umowy

37 Art. $860-875$ k.c.

38 Odróżnianej od pierwotności odpowiedzialności charakteryzującej spółkę cywilną, art. 864 k.c.

39 Pozytywnie o kapitale zakładowym jako o teście powagi M. Żurek, W poszukiwaniu optymalnego modelu regulacji struktury majątkowej spółki z o.o. - ujęcie prawno-ekonomiczne, „Przegląd Prawa Handlowego" 2016, nr 5; P. Kindler, The Single-Member Limited Liability Company (SUP): A Necessary Reform of EU Law on Business Organizations?, Monachium 2016, s. 21. 
spółki, miałaby stanowić test powagi) wydaje się nierealne ze względu na brak kryteriów symboliczności i brak podstaw do odniesienia jej in casu do zamierzonego celu gospodarczego spółki i zakresu działania ${ }^{40}$. Po drugie, na gruncie spółek kapitałowych kapitał zakładowy, którego pokrycie w minimalnej ustawowej wysokości jest $\mathrm{w}$ istocie owym testem powagi, wyraża także granicę zaangażowania kapitałowego wspólnika i granicę jego ryzyka. Tymczasem w spółce osobowej w kontekście nieograniczonej, solidarnej ze spółką odpowiedzialności wspólnika to właśnie wzięcie na siebie ciężaru tej odpowiedzialności stanowi rzeczywisty test powagi.

Funkcja wzmacniania bezpieczeństwa obrotu wiąże się również z ochroną wierzycieli. W praktyce jednak zakaz powstawania bezwkładowych spółek osobowych nie wpływa jakkolwiek na położenie wierzycieli spółek osobowych. Jeżeli chodzi o regulacje utrzymania majątku spółki, to jedyny znany ustawie instrument ochrony majątku spółki osobowej — zakaz zmniejszania udziału kapitałowego - powiązany jest, co oczywiste, z udziałem kapitałowym. Ten zaś, jak wskazano, nie pozostaje w jakiejkolwiek relacji z obowiązkiem wnoszenia wkładów, lecz z praktyczną sferą partycypacji majątkowej wspólnika w spółkach. Należy też zwrócić uwagę, że w praktyce wniesione wkłady mogą zostać w sposób praktycznie niekontrolowalny spieniężone i utracone. W praktyce rynkowej wierzyciele spółek kapitałowych, mimo rozbudowanego instrumentarium ochrony ich kapitału zakładowego, i tak sięgają po inne środki ochrony, co w jasny sposób sugeruje, że ochrona wierzycieli poprzez teoretyczne zakazy uszczuplania majątku jest co najmniej niewystarczająca ${ }^{41}$. Przede wszystkim jednak, inaczej niż w spółkach kapitałowych, najdonioślejszym środkiem ochrony wierzycieli w spółkach osobowych pozostaje subsydiarna odpowiedzialność wspólników (art. 31 k.s.h., znajdujący także odpowiednie zastosowanie na mocy stosownych odesłań w ramach regulacji innych spółek).

Rozważania o teście powagi i kapitale zakładowym prowadzą nieuchronnie do spółek kapitałowych. Czy badanie ich regulacji jest w stanie pomóc ujawnić inne funkcje obligatoryjnych wkładów w spółkach osobowych (z zastrzeżeniem odrębności regulacji tych rodzin spółek oraz niedopuszczalności analogicznego stosowania przepisów k.s.h. dotyczących jednych lub drugich)? Doktryna prawa spółek kapitałowych wyróżnia trzy zasadnicze funkcje kapitału zakładowe-

40 Zob. trafne uwagi A.W. Wiśniewskiego (Kilka uwag $w$ sprawie reformy prawa osobowych spótek handlowych, „Przegląd Prawa Handlowego” 2012, nr 9, s. 26-30), który na obrazowych przykładach ukazuje problemy, z jakimi w efekcie trzeba się zmierzyć w ramach kazuistycznej oceny wkładów w kategoriach ich realności, względnie symboliczności

41 A. Radwan, Sens i nonsens kapitału zakładowego - przyczynek do ekonomicznej analizy ustawowej ochrony wierzycieli spółek kapitałowych, [w:] M. Cejmer, J. Napierała, T. Sójka, Europejskie prawo spółek, t. 2. Instytucje prawne dyrektywy kapitałowej, Kraków 2005, s. 74. 
go: prawną, ekonomiczną oraz ochronną ${ }^{42}$, zwaną też niekiedy gwarancyjną. Tę ostatnią można sprowadzić do zagadnień ochrony i trwałości kapitału i ochrony wierzycieli, co zostało już omówione. Funkcja prawna, związana z charakterem kapitału zakładowego jako sumy udziałów, wyraża się w tym, że na jego podstawie określana jest pozycja wspólnika w spółce ${ }^{43}$. W spółkach osobowych w sytuacji braku odmiennego ujęcia tej kwestii w umowie spółki funkcję identyfikowania i określania pozycji wspólnika spełnia co do zasady udział kapitałowy, który w swej istocie nie jest zależny od istnienia wymogu wniesienia do spółki wkładu, lecz opiera się jedynie na wkładzie rzeczywiście wniesionym. Nie sposób zatem dostrzec w obowiązku wniesienia wkładu występowania takiej funkcji. Funkcja ekonomiczna z kolei sprowadza się do związku z prowadzoną działalnością spół$\mathrm{ki}^{44}$. Można w tej mierze mówić o wkładach w kontekście przydania spółce finansowych środków na działalność (zalicza się tutaj aspekt kwotowy) bądź innych przedmiotów mających bezpośrednio służyć działalności (aspekt celowościowy). Jak wskazano, tak naprawdę jest to praktyczna problematyka ukształtowania umowy spółki i pomysłu wspólników na przedsięwzięcie gospodarcze. Należy podkreślić, że nie jest jasne, na czym miałaby polegać weryfikacja wkładów pod kątem tak rozumianej funkcji ekonomicznej. Sądy rejestrowe nie posiadają procesowego instrumentarium ani materialnoprawnej podstawy oceny wkładów w tym kontekście ${ }^{45}$. W przypadku braku jakichkolwiek sztywnych wymogów ustawowych co do wartości wkładów oraz terminów ich wniesienia konieczne jest opieranie się na niezwykle mętnych i niejasnych kryteriach celem dokonywania bardzo kazuistycznej oceny. Należy dodać, że istnienie od samego początku konkretnej masy majątkowej, na podstawie której można prowadzić działalność, nie jest konieczne do przyjęcia podmiotowości prawnej. Polski porządek prawny zna przypadki osobowości prawnej oderwanej od wymogów wniesienia jakiegokolwiek kapitału początkowego, np. stowarzyszenia, spółdzielnie. Również zagraniczne przykłady tzw. spółek praktycznie bezkapitałowych (almost capital-less ${ }^{46}$ ) zdają się wskazywać na taką możliwość.

Pojawia się zatem pytanie, na czym miałaby polegać rola wkładów w spółkach osobowych jako koniecznego elementu ich umów, którego brak powoduje nie-

42 Zob. A. Herbet, [w:] System Prawa Prywatnego, t. 17A. Prawo spótek kapitałowych, red. S. Sołtysiński, wyd. 2, Warszawa 2016, s. 227; A. Rachwał, [w:] System Prawa Handlowego, t. 2, s. 769.

43 R. Potrzeszcz, T. Siemiątkowski, [w:] Kodeks spółek handlowych. Komentarz, t. 1, red. T. Siemiątkowski, R. Potrzeszcz, s. 293. Wyróżnia się także cokolwiek autoteliczny aspekt funkcji prawnej polegający na tym, że kapitał zakładowy stanowi warunek utworzenia spółki, zob.

A. Kidyba, [w:] idem, Kodeks..., s. 570.

44 A. Rachwał, op. cit., s. 769.

45 M. Romanowski, op. cit., s. 126.

46 A. Bartolacelli, Almost capital-less companies in Europe: Trends, variations, competition, „European Company and Financial Law Review” 2017, s. 187 n. 
ważność umowy spółki? Jakie względy przemawiają za zakazem powstawania osobowych spółek bezwkładowych?

\section{Podsumowanie. Uwagi de lege ferenda}

Wydaje się, że przeprowadzona analiza pozwala uznać, że wymóg wniesienia wkładów w spółkach osobowych stanowi pewien anachronizm. Jego istnienia nie da się uzasadnić przekonującymi argumentami — zarówno w kwestii znaczenia dla stosunków wewnętrznych spółki i praktyki prowadzenia jej spraw, jak i w zakresie jej stosunków z osobami trzecimi. Nie sposób zidentyfikować takich funkcji ukształtowania wkładów jako obligatoryjnego składnika umów spółek osobowych, nawet korzystając z dorobku doktryny spółek kapitałowych, które uzasadniałyby zakaz powstawania spółek bezwkładowych. W sytuacji, w której podstawowym środkiem ochrony wierzycieli i obrotu jest w spółkach osobowych odpowiedzialność osobista wspólników, tracą sens wszelkie instrumenty ochrony jej majątku. Zagadnienie wyposażenia spółki w majątek i środki odpowiednie do prowadzenia zamierzonej działalności winno być problemem pozostawionym decyzji wspólników, których zresztą w pełni obciąża ryzyko błędu czy niefrasobliwości.

Jak wskazano, obowiązek zarówno wniesienia wkładów, jak i objęcia ich umowami spółek osobowych istotnie komplikuje procedurę zakładania takich spółek, wikłając wspólników w skomplikowane prawniczo kwestie świadczeń na rzecz nieistniejącego podmiotu. Szczególnie istotne jest to w przypadku nieruchomości i praw na nieruchomościach.

$\mathrm{Z}$ uwagi na to można wysunąc postulat de lege ferenda, aby ustawodawca zrezygnował z ujęcia określenia w umowie spółki i wniesienia wkładu do spółek osobowych jako obligatoryjnego, jednocześnie pozwalając na tworzenie spółek bezwkładowych. Takie rozwiązanie wydaje się korzystne z punktu widzenia deklarowanych starań poprawy i uproszczenia otoczenia prawnego przedsiębiorców i regulacji wykonywania działalności gospodarczej. Należy podkreślić, że znaczącemu praktycznemu uproszczeniu nie towarzyszyłoby w zasadzie jakiekolwiek istotne zwiększenie ryzyka bądź kosztów transakcyjnych lub informacyjnych w obrocie gospodarczym.

W przypadku uznania, że nadmierna liberalizacja regulacji spółek osobowych jest potencjalnie groźna (np. wskutek przyjęcia, że rezygnacja z obligatoryjności wkładów będzie skutkować negatywnymi implikacjami wizerunkowymi, doprowadzając do ograniczenia zaufania do spółek osobowych w obrocie), można zaproponować sięgnięcie po pewne rozwiązania mitygujące ryzyko. Po pierwsze, w zgodzie z istotą i naturą spółki osobowej można wyobrazić sobie zmianę warunków odpowiedzialności wspólników, np. w zakresie ułatwień jej dochodzenia bądź też w drodze modyfikacji represyjnych w charakterze — przykładowo, re- 
zygnacja z kryterium subsydiarności otwierająca możliwość kierowania egzekucji do majątku wspólnika bez uprzedniego egzekwowania spółki jako sankcja za niedopuszczalne wypłaty z majątku spółki. Po drugie, można przewidzieć dla spółki bezwkładowej obowiązek tworzenia stosownych rezerw do momentu osiągnięcia pożądanego pułapu kapitałów własnych, co jest rozwiązaniem znanym z kontynentalnych regulacji bezkapitałowych spółek z ograniczoną odpowiedzialnością 47 .

\section{Bibliografia}

Allerhand M., Kodeks handlowy. Komentarz, t. 1. Spółka jawna. Spótka komandytowa, Lwów 1935, reprint Bielsko-Biała, wyd. 1991.

Bartolacelli A., Almost capital-less companies in Europe: Trends, variations, competition, „European Company and Financial Law Review" 2017.

Bieniak J., Bieniak M., Nita-Jagielski G., Oplustil K., Pabis R., Rachwał A., Spyra M., Suliński G., Tofel M., Zawłocki R., Kodeks spółek handlowych. Komentarz, Warszawa 2011.

Bieniek G., Nieruchomość jako wkład niepieniężny, [w:] Prawo prywatne czasu przemian. Księga pamiątkowa dedykowana Profesorowi Stanisławowi Soltysińskiemu, red. A. Nowicka, Poznań 2005.

Cejmer M., Napierała J., Sójka T., Europejskie prawo spótek, t. 2. Instytucje prawne dyrektywy kapitałowej, Kraków 2005.

Gomoła M., Wierzytelność jako przedmiot wkładu do spótki kapitałowej - wybrane zagadnienia, „Prawo Spółek” 2002, nr 10.

Gorczyński G., Umowa spótki jawnej, [w:] Europeizacja prawa prywatnego, t. 1, red. M. Pazdan, W. Popiołek, E. Rott-Pietrzyk, M. Szpunar, Warszawa 2008.

Górecki W., Konstrukcja wnoszenia przez wspólników wkładów do handlowych spółek osobowych, „Transformacje Prawa Prywatnego" 2012, nr 2.

Kappes A., Uwagi o rozliczeniach z występującym (wyłaczanym) wspólnikiem handlowej spótki osobowej, „Przegląd Prawa Handlowego” 2012, nr 7.

Kidyba A., Handlowe spółki osobowe, wyd. 3, Warszawa 2010.

Kidyba A., Kodeks spółek handlowych. Komentarz, t. 1. wyd. 10, Warszawa 2013.

Kidyba A., Kopaczyńska-Pieczniak K., Ogólna charakterystyka stosunków majątkowych w spótce komandytowej, „Przegląd Prawa Handlowego” 1995, nr 6.

Kindler P., The Single-Member Limited Liability Company (SUP): A Necessary Reform of EU Law on Business Organizations?, Monachium 2016.

Kodeks cywilny, t. 2. Komentarz do art. 450-1088, red. M. Gutowski, Legalis/el. 2016.

Kodeks cywilny. Komentarz, red. E. Gniewek, wyd. 6, Warszawa 2014.

Kodeks handlowy. Komentarz, red. K. Kruczalak, Warszawa 1998.

Kodeks spótek handlowych. Komentarz, red. Z. Jara, Warszawa 2014.

Kodeks spółek handlowych. Komentarz, red. K. Kruczalak K., Warszawa 2001.

Kodeks spótek handlowych. Komentarz, red. W. Pyzioł, Warszawa 2008.

Kodeks spótek handlowych. Komentarz, red. J.A. Strzępka, Warszawa 2013.

Kopaczyńska-Pieczniak K., Pozycja prawna wspólnika spółki jawnej, Warszawa 2012.

47 Na obowiązek tworzenia kapitału zapasowego poprzez obowiązkowe odpisy z zysku zdecydował się ustawodawca niemiecki w ramach regulacji UG (die Unternehmergesellschaft). Zob. M. Lutter, Reforma GmbH w Niemczech, „Monitor Prawniczy” 2008, nr 29, s. 1266-1269; J. Schmidt, Die SUP aus der Sicht der Kommission und ihr Kapitalschutz, [w:] M. Lutter, J. Koch, Societas Unius Personae (SUP), Berlin 2015, s. 9. 
Kutyła M., Prawa na nieruchomości jako aport, „Monitor Prawniczy” 1999, nr 4.

Litwińska M., Typologia spółek w Kodeksie spółek handlowych, „Przegląd Ustawodawstwa Gospodarczego" 2001, nr 2.

Litwińska-Werner M., Kodeks spółek handlowych. Komentarz, wyd. 3, Warszawa 2007.

Lutter M., Reforma GmbH w Niemczech, „Monitor Prawniczy” 2008, nr 29.

Lutter M., Koch J., Societas Unius Personae (SUP), Berlin 2015.

Maciąg M., Kilka uwag na temat wniesienia prawa użytkowania wieczystego jako aportu do spótki kapitałowej, ,Prawo Spółek” 2008, nr 7-8.

Malarewicz A., Sakowicz A., Wierzytelność wspólnika-akcjonariusza wobec spótki kapitałowej jako przedmiot potracenia i konwersji, cz. I, „Prawo Spółek” 2007, nr 3.

Maleszczyk E., Udział kapitałowy w spótce jawnej, „Przegląd Prawa Handlowego” 2004, nr 1.

Minas M., Aport w spółce kapitałowej, Gdańsk 2005.

Minas M., Odpowiedzialność cywilna za niewykonanie lub nienależyte wykonanie obowiazków związanych z wniesieniem wkładu niepieniężnego do spótki z ograniczona odpowiedzialnościa lub spótki akcyjnej, „Rejent” 1994, nr 1.

Minas M., Zdolność aportowa, „Rejent” 1995, nr 9.

Mróz T., Przedmiot wkładu a funkcje kapitału zakładowego, „Monitor Prawniczy” 2002, nr 5.

Naworski J.P., Potrzeszcz R., Siemiątkowski T., Strzelczyk K., Kodeks spółek handlowych. Komentarz, t. 1, red. T. Siemiątkowski, R. Potrzeszcz, Warszawa 2010.

Nita-Jagielski G., O potrzebie zmian regulacji prawnych dotyczacych powstania osobowej spótki handlowej, „Przegląd Prawa Handlowego” 2012, nr 10.

Nowacki A., Udział kapitałowy w spółce jawnej, „Przegląd Prawa Handlowego” 2004, nr 6.

Pinior P., O potrzebie zmian prawa spótek handlowych $w$ zakresie regulacji spółek osobowych, „Przegląd Prawa Handlowego" 2012, nr 9.

Prawo spótek, red. A. Kidyba, Warszawa 2007/2008.

Pyzioł W., Szumański A., Weiss I., Prawo spótek, Warszawa 2014.

Rachwał A., Spyra M., Umowa spótki jawnej, partnerskiej, komandytowej, Warszawa 2009.

Radwański Z., [w:] System Prawa Prywatnego, t. 2. Prawo cywilne - część ogólna, red. Z. Radwański, Warszawa 2008.

Rodzynkiewicz M., Kodeks spótek handlowych. Komentarz, Warszawa 2013.

Sołtysiński S., Szajkowski A., Szumański A., Szwaja J., Gawałkiewicz R., Herbet A., Mika I.B., Tarska M., Kodeks spółek handlowych. Komentarz, t. 1, wyd. 3, Warszawa 2012.

System Prawa Handlowego, t. 2A. Prawo spółek handlowych, red. S. Włodyka, Warszawa 2007.

System Prawa Prywatnego, t. 16. Prawo spótek osobowych, red. A. Szajkowski, Warszawa 2008.

System Prawa Prywatnego, t. 17B. Prawo spółek kapitałowych, red. S. Sołtysiński, Warszawa 2010.

Szumański A., Kodeks spółek handlowych z rządowym uzasadnieniem projektu ustawy i skorowidzem, Kraków 2001.

Szumański A., Pojęcie i przedmiot aportu do spótki akcyjnej, „Przegląd Prawa Handlowego” 1995, nr 1.

Szumański A., Wkłady niepieniężne do spótek kapitałowych, Warszawa 1997.

Szwaja J., Nowy kodeks spółek handlowych, cz. I, „Prawo Spółek” 2001, nr 1.

Wiśniewski A.W., Kilka uwag w sprawie reformy prawa osobowych spótek handlowych, „Przegląd Prawa Handlowego" 2012, nr 9.

Wiśniewski A.W., Prawo o spółkach, podręcznik praktyczny, t. 2, Warszawa 1991.

Wkłady niepieniężne w spótkach handlowych, red. W. Popiołek, Warszawa 2014.

Wręczycka K., Wniesienie nieruchomości na własność do spótek osobowych, „Rejent” 2004, nr 9.

Żurek M., W poszukiwaniu optymalnego modelu regulacji struktury majątkowej spótki z o.o. - ujęcie prawno-ekonomiczne, „Przegląd Prawa Handlowego” 2016, nr 5. 


\section{Akty prawne}

Ustawa z dnia 15 września 2000 roku — Kodeks spółek handlowych (tekst jedn. Dz.U. z 2017 r. poz. $1577 \mathrm{ze} \mathrm{zm}$.).

Ustawa z dnia 23 kwietnia 1964 roku — Kodeks cywilny (tekst jedn. Dz.U. z 2017 r. poz. 459 ze zm.).

\section{Orzecznictwo}

Postanowienie Sądu Najwyższego z dnia 14 stycznia 2015 roku, sygn. II CSK 85/14.

Postanowienie Sądu Najwyższego z dnia 25 listopada 2015 roku, sygn. II CSK 723/14.

Uchwała Sądu Najwyższego z dnia 5 grudnia 1991 roku, sygn. III CZP 128/91, OSN 1992, nr 6, poz. 106.

Uchwała Sądu Najwyższego z dnia 20 maja 1992 roku, sygn. III CZP 52/92, OSP 1993 z. 6, poz. 120.

Uchwała Sądu Najwyższego z dnia 2 marca 1993 roku, sygn. III CZP 123/92, OSNC 1993, nr 10, poz. 167.

Wyrok Sądu Najwyższego z dnia 11 września 1945 roku, sygn. C I 62/45, OSNC 1945-1946, nr 1, poz. 6.

\section{The obligation to make contributions to partnerships. Critical remarks}

\section{Summary}

It is submitted that the statutory requirement to contribute to partnerships is not justified neither by the function they may perform nor by business risk, in particular pertaining to creditors. Given that the basic means of creditor protection in partnerships is the personal liability of partners, all instruments aimed at protecting the partnerships' assets seem obsolete. Equipping the partnership with property rights and resources appropriate for the purpose of intended activity should be a problem left to the partners' decision - who, moreover, fully bear the risk of error or carelessness. The requirement to both provide for contributions in partnerships' agreements complicates significantly the procedure of setting up such companies, entangling partners into complex legal issues of performing obligations to the benefit of a non-yet-existent partnership. This proves particularly burdensome in the case of real property and rights in rem. Hence it is suggested that the legislator allow the creation of contribution-less partnerships. Such solution seems to be beneficial taking into account the context of declared efforts to improve and simplify the legal environment of entrepreneurs and business regulations. Significant practical simplification would not be accompanied by any significant increase in risks, especially regarding transaction or information costs. However, supplementary solutions are also possible: facilitating the pursuit of partners' liability, including sanctions for inappropriate actions, or the obligation to create reserves until capital in a satisfactory amount is obtained. 